\title{
ANALISIS SYARIAH TERHADAP KONSEP PEMILIKAN BERMANFAAT (BENEFICIAL OWNERSHIP) DALAM PEMBIAYAAN PERUMAHAN
}

\author{
Shari'ah Analysis on The Concept of Beneficial Ownership in Home \\ Financing
}

\author{
NiK ABdul Rahim NiK AbDUl GHANI \\ MAT NOOR MAT ZAIN \\ SALMY EDAWATI YAACOB \\ RUZIAN MARKOM \\ AHMAD DAHLAN SALLEH \\ MOHAMMAD Firdaus MOHAMMAd HatTA \\ AMIR FAZLIM YUSOFF \\ HANZALAH ZAINAL
}

\begin{abstract}
ABSTRAK
Pemilikan aset merupakan aspek penting dalam pembiayaan perumahan secara Islam yang melibatkan kontrak jual beli. Walau bagaimanapun, isu pemilikan bermanfaat menjadi topik yang hangat diperdebatkan berikutan sistem kewangan Islam yang beroperasi dalam kerangka konvensional perundangan Malaysia. Kedudukan pemilikan bermanfaat dianggap bertentangan dengan konsep pemilikan dalam Islam sekaligus menyanggahi maqasid Syariah. Artikel ini bertujuan mengkaji kedudukan pemilikan bermanfaat daripada perspektif Syariah. Kajian ini menganalisis maksud dan ciri-ciri pemilikan dalam Islam seterusnya menghuraikan asal-usul pemilikan bermanfaat dari sudut perundangan. Kajian ini juga menjelaskan beberapa aplikasi semasa pemilikan bermanfaat dalam pembiayaan perumahan secara Islam dari aspek Syariah. Kajian ini menggunakan pendekatan analisis kandungan bagi menjelaskan konsep pemilikan bermanfaat. Hasil kajian mendapati pemilikan bermanfaaat diiktiraf sebagai pemilikan sebenar kerana Syariah membenarkan pemindahan pemilikan sebaik sahaja ijab dan qabul terlaksana.
\end{abstract}

Kata kunci: Pemilikan bermanfaat, pembiayaan perumahan, pemilikan, kewangan Islam

\begin{abstract}
ABSRACT
Ownership of asset is a crucial aspect of Islamic home financing which involves a sale contract. Nevertheless, the issue of beneficial ownership has been seriously discussed since the system of Islamic finance operates within the Malaysian conventional legal framework. The status of beneficial ownership is claimed as contradict to the concept of ownership in Islam which in turn violate the maqasid Shariah. This article aims to study the status of beneficial ownership from the Shariah perspective. This study examines the meaning of ownership and its characteristics from the Islamic perspective and discusses the origin of beneficial ownership from the legal perspective. It also discusses some current applications of the beneficial ownership in Islamic home financing from the Shariah aspect. The approach of content analysis is applied to clarify the concept of beneficial ownership. The research finding discovers that the beneficial ownership is recognized as a real ownership due to the fact that Shariah allows the transfer of ownership after the execution of ijab and qabul.
\end{abstract}

Keyword: Beneficial ownership, home financing, ownership, Islamic finance 


\section{PENDAHULUAN}

Pembiayaan perumahan Islam semakin mendapat perhatian masyarakat Islam dan bukan Islam hari ini. Ini kerana menurut perspektif Islam, pinjaman perumahan konvensional adalah berasaskan riba dan riba menjadi sebab utama pengharamannya. Sehubungan itu, pembiayaan perumahan Islam telah menjadi alternatif bagi mendapatkan pembiayaan di kalangan masyarakat terutama masyarakat Islam. Manakala masyarakat bukan Islam menerima konsep pembiayaan perumahan Islam kerana ia dianggap lebih beretika dan bermoral. Dalam konteks semasa terdapat banyak produk pembiayaan perumahan Islam yang ditawarkan seperti pembiayaan perumahan Musharakah Mutanaqisah (MM), pembiayaan berasaskan murabahah Bay' Bithaman Ajil (BBA) dan al-Ijarah alMuntahiyat Bi al-Tamlik (IMBT) (Asyraf Wajdi \& Nurdianawati 2014).

Walau bagaimanapun, pembiayaan perumahan Islam tidak terlepas daripada isu-isu Syariah yang wujud dalam sesuatu produk. Antara kritikan yang menjadi perdebatan hangat di kalangan sarjana Syariah ialah isu pemilikan bermanfaat atau beneficial ownership (Asyraf Wajdi \& Nurdianawati 2014; Engku Rabiah Adawiah 2014; Nik Abdul Ghani et al. 2015; Ramadhan Fitri 2013). Isu ini telah dipertikaikan kerana dianggap telah melanggar konsep pemilikan yang digariskan oleh Syariah dan telah membawa kepada pelanggaran maqasid Syariah (Nik Abdul Rahim et al. 2015). Hal ini berlaku kerana, selain daripada kerangka kerja hukum Syariah, industri kewangan Islam juga perlu mematuhi kerangka kerja undang-undang dan kawalan selia yang sama seperti konvensional. Ini merupakan cabaran besar buat kewangan Islam untuk beroperasi sesuai dengan lingkungan kerangka kerja Syariah.

Bahagian awal kertas kerja ini akan menghuraikan konsep pemilikan dalam Islam meliputi definisi dan pembahagian pemilikan dalam Islam. Seterusnya ia akan diikuti oleh perbincangan mengenai kemunculan istilah pemilikan bermanfaat yang diaplikasikan menerusi prinsip ekuiti di United Kingdom. Huraian lanjut akan menyentuh aplikasi pemilikan bermanfaat dalam kewangan Islam sebelum melakukan analisis Syariah terhadap konsep pemilikan bermanfaat dalam pembiayaan perumahan.

\section{PEMILIKAN MENURUT PERSPEKTIF SYARIAH}

\section{Definisi Pemilikan (Milkiyyah)}

Pemilikan dalam bahasa Arab disebut sebagai milk (ملكية) atau milkiyyah (ملكية). Secara epistemologi, kata akar berasal daripada tiga huruf (mim, lam dan kaf) merujuk kepada kekuatan dan kesihatan pada sesuatu (quwwah fi al-shay' wa sihhah) (Ibnu Faris). Ibn Manzur (1955) menyatakan di dalam Lisan al-Arab kalimah malk, mulk, milk bermaksud keadaan menguasai sesuatu dan keupayaan bertindak melupuskan sesuatu yang dimiliki. Manakala dari segi istilah, terdapat pelbagai definisi yang dikemukakan oleh para fuqaha mazhab empat seperti berikut:

\section{Definisi Pemilikan menurut Mazhab Hanafi}

Ibn Nujaim (1999) dan Ibn Hummam (t.th.) mendefinisikannya sebagai: 


$$
\text { قدرة يثتبها الثنار ع ابتداء على التصرف (إلا لمانع) }
$$

Maksudnya: Kemampuan asal yang ditetapkan oleh syarak bagi mengendalikan sesuatu harta melainkan jika terdapat halangan.

\section{Definisi Pemilikan menurut Mazhab Maliki}

Tokoh yang terkenal di dalam mazhab Maliki iaitu al-Qarafi (2003) telah memberikan definisi pemilikan seperti berikut:

$$
\text { و العوضم شر عي مقدر في العين أو المنفعة يقتضي تمكن من بض هن هناف إلبه من انتفاعه بالمملو ك }
$$

Maksudnya: Hukum syarak (mengikut perundangan yang sah) ditetapkan terhadap fizikal harta ataupun manfaat harta yang membolehkan seseorang untuk mengambil faedah daripada harta yang dimiliki dan menerima pampasan daripadanya.

\section{Definisi Pemilikan menurut Mazhab Syafi'i}

al-Suyuti (1983) di dalam kitabnya al-Ashbah wa al-Nazair telah menukilkan kata-kata Ibn al-Subki seperti berikut:

$$
\text { من حم شرعي يقدر في عين أو منفعة يقتضي تمكن من ينسب إلبه من انتفاعه و العوض عنه }
$$

Maksudnya: Hukum syarak (mengikut perundangan yang sah) yang ditetapkan terhadap fizikal harta ataupun manfaat yang diberikan kepada seseorang supaya beliau dapat mengambil faedah dan menerima pampasan daripadanya.

\section{Definisi Pemilikan menurut Mazhab Hanbali}

Ibn Taimiyyah (2005) telah meletakkan definisi pemilikan sebagai:

$$
\text { القدرة الثرعية على التصرف في الرقبة }
$$

Maksudnya: Keupayaan yang sah untuk mengendalikan sesuatu harta.

Berdasarkan kepada definisi-definisi yang dikemukakan oleh para ulama silam, maksud pemilikan didapati terbina di atas beberapa unsur. Unsur-unsur ini mampu membentuk satu kefahaman yang lebih komprehensif terhadap maksud pemilikan itu sendiri (al-Umari 2003). Antara unsur-unsur tersebut ialah:

i. Pemilikan merupakan hubungan eksklusif dan absah di sisi perundangan.

ii. Hubungan eksklusif ini terbina antara manusia dan harta yang dimiliki.

iii. Matlamat daripada hubungan eksklusif tersebut membawa kepada keupayaan seseorang (pemilik) untuk mengeksploitasi dan mengambil faedah daripada harta yang dimiliki. Hal ini bersesuaian dengan hakikat pemilikan.

iv. Keupayaan seseorang (pemilik) untuk mengeksploitasi dan mengambil faedah daripada harta yang dimiliki telah menjadi penghalang kepada orang lain (selain daripada pemilik) untuk mendapat hak yang sama.

v. Keupayaan mengeksploitasi dan mengambil faedah daripada harta boleh dilakukan samada melalui pemilik sendiri atau diwakilkan kepada orang lain. 


\section{Pembahagian Pemilikan}

Pemilikan boleh dikategorikan mengikut beberapa perspektif. Kategori berdasarkan kapasiti pemilikan dapat dibahagikan kepada dua bahagian iaitu pemilikan penuh (milk tam) dan pemilikan separa penuh (milk naqis).

\section{Pemilikan penuh (milk tam)}

Bermaksud, seseorang memiliki fizikal dan manfaat harta tersebut secara bersama. Ibn Rajab (t.th.) menyatakan bahawa pemilikan ini terjadi disebabkan beberapa kaedah transaksi tertentu seperti jual beli, hibah, wasiat dan lain-lain. Melalui pemilikan yang diperolehi daripada kaedah yang disebutkan, seseorang memiliki harta tersebut secara penuh iaitu beliau milik kepada fizikal dan manfaat harta tersebut.

\section{Pemilikan separa penuh (milk naqis)}

Pemilikan separa penuh (naqis) boleh dipecahkan kepada beberapa pecahan (al-Umari 2003; Badran t.th.; Ibn Rajab t.th.). Ibn Rajab (t.th.) telah memecahkan kepada tiga pecahan yang kecil. Pecahan tersebut ialah, pemilikan terhadap fizikal harta tanpa memiliki manfaatnya. Kedua, pemilikan terhadap manfaat harta tanpa memiliki fizikalnya dan ketiga ialah memiliki hak untuk mengambil manfaat daripada harta tetapi beliau tidak memiliki manfaat harta tersebut. Kesemua pecahan yang disebutkan merupakan pemilikan separa penuh kerana seseorang tidak memiliki fizikal dan manfaat harta secara bersama dalam suatu masa.

\section{Pemilikan Fizikal Harta Tanpa Memiliki Manfaatnya (Milk'Ayn Bi La Manfaah)}

Pemilikan terhadap fizikal harta tanpa memiliki manfaatnya merupakan perkara yang dibenarkan oleh syarak. Walaupun pada asalnya seseorang mempunyai pemilikan penuh terhadap sesuatu harta, namun, terdapat kes-kes tertentu pemilikannya berubah menjadi separa penuh. Hal ini boleh berlaku apabila seseorang memiliki fizikal sesuatu harta, sedangkan dalam masa yang sama seseorang yang lain memiliki manfaat harta tersebut (al-Umari 2003; Badran t.th.). Sebagai contoh di dalam kes wasiat. Seseorang mewasiatkan manfaat rumahnya kepada orang lain sepanjang hayatnya ataupun beberapa tempoh yang ditetapkan.

Dalam hal ini, fizikal rumah masih lagi milik pewasiat, manakala manfaatnya sahaja merupakan milik penerima wasiat. Apabila pewasiat mati, manfaat rumah tersebut berpindah menjadi milik penerima wasiat selama tempoh hidupnya atau tempoh yang ditetapkan. Sedangkan fizikal rumah berpindah kepada ahli waris si mati (pewasiat) dan ahli waris tidak memiliki langsung manfaat rumah tersebut. Hal ini berterusan selama penerima wasiat memiliki hak terhadap manfaat harta tersebut. Apabila penerima wasiat mati atau tamat tempoh yang ditetapkan dalam wasiat, maka manfaat tersebut kembali kepada ahli waris (pemilik fizikal) dan pemilikan ahli waris terhadap harta tersebut berubah menjadi pemilikan penuh (milk tam) (al-Umari 2003).

\section{Pemilikan Manfaat Harta Tanpa Memiliki Fizikalnya (Milk Manfaah Bi La 'Ayn)}


Seseorang dikatakan memiliki manfaat sesuatu harta apabila beliau mempunyai autoriti dan keupayaan untuk menguruskan manfaat harta tersebut, dalam masa yang sama orang lain tiada hak yang sedemikian (Badran t.th.). Dalam konteks ini, beliau memiliki manfaat harta tersebut, sedangkan pemilik bagi fizikal harta tersebut merupakan orang lain. Situasi ini boleh berlaku samada pemilik manfaat mendapat hak tersebut menerusi imbalan ataupun tidak, bergantung kepada aqad yang dipersetujui bagi kedua-dua belah pihak (Badran t.th.).

al-Umari (2003) dan Badran (t.th.) menyatakan terdapat beberapa sebab terjadi pemilikan terhadap manfaat antaranya sewaan, pinjaman, wasiat, wakaf dan lain-lain lagi. Bagi konteks sewaan, penyewa memiliki manfaat terhadap barang yang disewa sementara pemilik asal kekal memiliki fizikal harta tersebut. Perkara yang sama turut berlaku sekiranya seseorang mewasiatkan manfaat hartanya kepada penerima wasiat untuk suatu tempoh yang ditetapkan selepas kematiannya. Penerima wasiat akan memiliki manfaat berdasarkan wasiat yang dikemukakan oleh pewasiat. Selepas tamat tempoh tersebut, manfaat harta tersebut kembali kepada ahli waris pewasiat.

Walau bagaimanapun, pemilikan manfaat akan terbatal sekiranya luput tempoh yang dipersetujui antara kedua pihak. Selain itu menurut mazhab Hanafi, kematian pemilik manfaat juga merupakan salah satu punca pemilikan manfaat tidak dapat diteruskan ${ }^{1}$. Adapun, jika pemilik fizikal harta pula yang mengalami kematian, ia bergantung kepada jenis akad yang diputuskan oleh kedua pihak. Jika akad tabarru' seperti pinjaman, pemilikan terhadap manfaat terbatal kerana kematian pemberi pinjam. Ini kerana hubungan antara pemilik asal dan harta tersebut telah terputus menyebabkan akad pinjaman antara kedua pihak terbatal. Namun, jika akad seperti wasiat, pemilikan terhadap manfaat harta tidak terbatal kerana kematian pewasiat. Bahkan pemilikan terhadap manfaat baru sahaja bermula kerana wasiat terlaksana selepas kematian pewasiat. Hal ini berbeza-beza mengikut akad yang dikemukakan oleh kedua-dua belah pihak.

\section{Hak Menerima Manfaat (Milk Intifa')}

Para fuqaha Hanafiah tidak membezakan istilah pemilikan manfaat (milk manfaah) dan hak menerima manfaat (milk intifa') (al-Umari 2003; Badran t.th.). Sebaliknya mereka hanya menyatakan istilah bagi pemilikan terhadap manfaat semata-mata. Walaupun demikian, mereka tetap membezakan pemilikan terhadap manfaat sama ada pemilikan manfaat itu dengan imbalan ataupun tidak. Sebagai contoh, pemilikan terhadap manfaat menerusi sewaan dikenali sebagai pemilikan terhadap manfaat dengan imbalan. Apabila penyewa mahu memiliki manfaat sesuatu harta, sebagai imbalannya, beliau perlu membayar harga sewa (al-Umari 2003).

Adapun bagi pemilikan manfaat tanpa imbalan dapat dilihat menerusi akad pinjaman (i'arah). Jika seseorang mahu mendapatkan manfaat harta seperti kereta, tanpa perlu menyewa, beliau perlu memohon kebenaran untuk meminjam kereta tersebut. Akad seperti ini tidak memerlukan imbalan bagi mendapatkan manfaat harta tersebut. Natijah

\footnotetext{
${ }^{1}$ Menurut jumhur, kematian pemilik manfaat sebelum tamat tempoh dalam akad ijarah dan wasiat tidak membatalkan pemilikan tersebut. Sebaliknya pemilikan manfaat itu diwarisi oleh warisnya mengikut tempoh yang dipersetujui sebelum kematiannya.
} 
daripada akad ini, seseorang yang meminjam tidak boleh memindahkan pemilikan tersebut kepada orang lain, berbeza dengan akad sewaan.

Sebaliknya, bagi jumhur ulama seperti Malikiyyah, Shafi'iyyah dan Hanabilah, mereka membuat perbezaan istilah antara pemilikan terhadap manfaat dan hak menerima manfaat (al-Qarafi 2003; al-Suyuti 1983; Ibn Rajab t.th.). Bagi pemilikan terhadap manfaat (milk manfaah), seseorang dikehendaki memberi imbalan seperti sewaan. Sebaliknya, hak menerima manfaat (milk intifa') tidak memerlukan seseorang untuk memberi imbalan.

Hak menerima manfaat dapat difahami melalui beberapa situasi seperti penggunaan harta awam yang boleh dimanfaatkan bersama sebagai contoh, jalan raya, tempat letak kereta, jambatan dan lain-lain. Pihak yang menggunakan harta ini tidak memiliki manfaat harta tersebut, sebaliknya mendapat keizinan untuk menggunakannya semata-mata. Begitu juga dengan hak menerima manfaat melalui akad pinjaman ( $i$ 'arah), seseorang dibenarkan untuk menggunakan harta tersebut sesuai dengan keizinan yang diberikan oleh pemilik asal. Peminjam tidak boleh memindahkan hak tersebut kepada orang lain kerana beliau tidak memiliki manfaat harta tersebut. Sebaliknya, beliau hanya diberi keizinan untuk menggunakannya sahaja.

\section{PEMILIKAN BERMANFAAT (BENEFICIAL OWNERSHIP) MENURUT UNDANG-UNDANG INGGERIS}

Secara umumnya, pemilikan bermanfaat (beneficial ownership) biasa digunakan dalam konteks undang-undang Inggeris bagi menunjukkan maksud berlawanan dengan pemilikan undang-undang (legal ownership). Istilah ini muncul dalam sejarah prinsip ekuiti yang memisahkan antara pemilik undang-undang dan pemilik bermanfaat. Prinsip ekuiti ini telah membentuk undang-undang amanah sekitar kurun ke-12 (Hudson 2007).

Menurut Sir Arthur Underhill, amanah didefinisikan sebagai tanggungjawab ekuiti yang mengikat seseorang (pemegang amanah) untuk mengendalikan harta yang diamanahkan bagi manfaat benefisiari (penerima manfaat), penerima manfaat tersebut boleh jadi dirinya sendiri ataupun orang lain (Oakley 1998). Melalui definisi ini, Hudson (2007) menyatakan, amanah mempunyai empat elemen penting iaitu, ia mengikuti kaedah-kaedah ekuiti, memberikan hak harta kepada benefisiari, mengenakan tanggungjawab kepada pemegang amanah, di mana tanggungjawab itu merupakan amanah.

Pembentukan amanah merupakan konsep penting bagi prinsip ekuiti. Ekuiti berpegang kepada prinsip keadilan, kesaksamaan dan kebenaran. Secara umumnya, ekuiti merupakan satu cabang undang-undang yang ditadbir di bawah Mahkamah Chancery sebelum tergubalnya Akta Kehakiman 1873 (Pearce 2010). Kini, ekuiti bukanlah sebahagian undang-undang tetapi merupakan satu prinsip moral yang bersifat fleksibel terhadap kejumudan undang-undang. Menerusi ekuiti, keadilan dapat ditegakkan tatkala undang-undang yang berteraskan formaliti dilihat membawa ketempangan dalam pelaksanaannya. Dengan ini, ekuiti tidak memusnahkan undang-undang, sebaliknya 
berfungsi membantu undang-undang bagi mencapai keadilan (Lembaga Penyelidikan Undang-Undang 2008).

Justeru, melalui konsep amanah, timbul istilah pemilik undang-undang (legal owner) dan pemilik bermanfaat (beneficial owner). Perkataan "beneficial" ditakrifkan dalam Black's Law Dictionary edisi ke-8 (Garner 2004) sebagai "hak-hak yang diperoleh daripada sesuatu selain hakmilik undang-undang (legal title)". Manakala pemilik bermanfaat pula ialah seseorang yang diiktiraf dalam ekuiti sebagai pemilik sesuatu kerana manfaat harta itu kembali kepadanya biarpun hakmilik undang-undang (legal title) orang lain (Garner 2004). Istilah ini juga kadangkala disebut sebagai equitable owner. Sebaliknya, istilah pemilik undang-undang (legal owner) merupakan terma yang berlawanan dengan pemilik bermanfaat (beneficial owner). Menurut Garner (2004) pemilik undang-undang ialah seseorang yang diiktiraf di sisi undang-undang sebagai pemilik sesuatu, iaitu seseorang yang memegang hakmilik undang-undang (legal title) ke atas aset bagi manfaat orang lain. Dalam erti kata lain, apabila amanah diwujudkan terdapat dua pemilikan ke atas harta iaitu pemilik undang-undang dan pemilik bermanfaat. Di mana, pemilik undang-undang perlu melaksanakan amanah mengurus harta bagi manfaat pemilik bermanfaat (Pearce 2010).

Biasanya istilah pemilikan bermanfaat digunakan dalam hal ehwal berkaitan tanah. Undang-Undang Inggeris melalui Akta Hartanah 1925 merujuk istilah pemilik bermanfaat sebagai seseorang yang dalam proses menukar hakmilik hartanah. Menunjukkan harta itu sudahpun menjadi miliknya, hanya sahaja sedang melalui proses pertukaran nama (Burke 1977).

Berdasarkan definisi-definisi di atas, ini bermakna pemilik bermanfaat berhak menggunakan dan menikmati tanah yang dimilikinya meskipun masih belum didaftarkan atas namanya. Definisi yang sama turut direkodkan oleh Islamic Finance Law Harmonisation Committee (Bank Negara Malaysia 2013: 99) iaitu "a person who enjoys the benefits of land ownership even though the land title is in another's name". Ini menunjukkan bahawa pemilik bermanfaat ialah pemilik sebenar dari segi undang-undang yang menikmati segala manfaat dan faedah aset meskipun tidak mempunyai hakmilik undang-undang (legal title).

\section{Penerimaan Prinsip Ekuiti dalam Undang-Undang Tanah di Malaysia}

Pemilikan rumah di Malaysia tidak boleh lari daripada mengikuti sistem undang-undang tanah di Malaysia. Adalah penting untuk meneliti dan memahami sistem undang-undang ini bagi merungkai penerimaan prinsip ekuiti dalam perundangan tempatan.

Sistem undang-undang tanah di Malaysia telah melalui pelbagai modifikasi. Perkembangannya telah dipengaruhi oleh sumber perundangan yang beraneka terdiri daripada Undang-undang Islam, Adat Melayu, Undang-undang Belanda dan Undangundang Inggeris. Biarpun begitu, undang-undang tanah di Malaysia pada hari ini adalah berteraskan Sistem Torrens dalam segala urusan berkaitan dengan pentadbiran dan pemegangan tanah (Siti Noorafizah Azizan et al. 2009). 
Sistem Torrens atau sistem pendaftaran hakmilik memperuntukan bahawa pendaftaran adalah segala-galanya dan keterangan konklusif boleh diperolehi daripada pendaftaran. Perkara ini dijelaskan dalam seksyen 89 Kanun Tanah Negara 1965:

89. Konklusifnya dokumen hakmilik daftaran.

Tiap-tiap dokumen hakmilik daftaran yang telah didaftarkan dengan sempurna di bawah Bab ini hendaklah, tertakluk kepada peruntukan-peruntukan Akta ini, merupakan keterangan konklusif-

Bahawa hakmilik tanah yang disebut didalamnya adalah diletakhakkan ke atas orang atau badan buat masa itu dinamakan di dalamnya sebagai tuanpunya;

Perkara ini turut dikuatkan lagi dengan konsep hakmilik tidak boleh disangkal seperti peruntukan seksyen 340 (1) dalam akta sama yang menyebut:

\begin{abstract}
Hakmilik atau kepentingan mana-mana orang atau badan buat masa itu didaftarkan sebagai tuanpunya mana-mana tanah, atau atas nama siapa apa-apa pajakan, gadaian atau esmen adalah buat masa itu terdaftar, hendaklah, tertakluk kepada peruntukan-peruntukan berikut seksyen ini, tidak boleh disangkal.
\end{abstract}

Walau bagaimanapun, di dalam seksyen 3 Akta Sivil 1956 telah membenarkan pemakaian common law dan prinsip-prinsip ekuiti dalam perundangan tempatan. Biarpun begitu, penggunaannya adalah terhad kepada keadaan-keadaan bagi Negeri-negeri di Malaysia dan penduduk-penduduknya membenarkan dan tertakluk kepada kelayakankelayakan tertentu sebagaimana keadaan-keadaan tempatan menyebabkan perlu (Siti Noorafizah Azizan et al. 2009).

Walaupun terdapat sekatan pemakaian sistem perundangan tanah Inggeris dalam seksyen 6 Akta Sivil 1956, ini tidak bermaksud prinsip ekuiti tidak boleh diaplikasikan. Hal itu hanya merujuk kepada larangan penggunaan sistem perundangan tanah Inggeris dan bukannya prinsip ekuiti Inggeris. Sementara itu, keizinan pemakaian prinsip ekuiti telah diperakukan oleh seksyen 3 Akta Sivil 1956 di dalam kes jika terdapat kekosongan di dalam undang-undang tempatan dan kesesuaian kepada situasi tempatan dalam pengaplikasian ekuiti Inggeris (Siti Noorafizah Azizan et al. 2009).

Selain itu, seksyen 206 (3) Kanun Tanah Negara 1965 telah memberikan ruang yang lebih terbuka terhadap aplikasi prinsip ekuiti dalam undang-undang tanah di Malaysia. Seksyen 206 (3) menyatakan tiada apa jua dalam subseksyen (1) akan menyentuh operasi kontraktual mana-mana transaksi yang berhubungan dengan tanah berimilik atau apa-apa kepentingan di dalamnya. Ini menunjukkan subsekyen (3) mengiktiraf konsep ekuiti kerana ia mengiktiraf kontrak tanah yang tidak berdaftar.

Situasi ini memberikan gambaran bagaimana memahami aplikasi ekuiti seperti yang diperuntukan dalam seksyen 3 Akta Sivil 1956. Pemakaian ekuiti sepatutnya tidak dilihat terhad hanya kepada ekuiti Inggeris semata-mata, tetapi konsep ekuiti perlu dihayati dengan makna yang lebih luas iaitu mempromosikan keadilan, kesaksamaan dan kebenaran (Nor Asiah Mohamad 2008). Mana-mana hak yang tidak berdaftar masih lagi boleh diiktiraf oleh pihak yang terlibat dengan melaksanakan ketelitian dalam kontrak.

Oleh yang demikian, jelas bahawa Kanun Tanah Negara 1965 tidak menghalang pengwujudan kepentingan benefisial dalam pengoperasian hal ehwal tanah di Malaysia. Seksyen 3 Akta Sivil 1956 dan seksyen 206 (3) Kanun Tanah Negara telah memberi 
laluan terhadap pemakaian prinsip ekuiti dalam undang-undang tanah di Malaysia. Pemakaian prinsip ekuiti adalah tidak dihalang, tetapi perlu mengikut kesesuaian amalan di Malaysia.

\section{PEMILIKAN BERMANFAAT (BENEFICIAL OWNERSHIP) DALAM KEWANGAN ISLAM}

Produk-produk yang ditawarkan dalam industri kewangan Islam perlu meletakkan aset sandaran sebagai pendasar untuk melaksanakan sesuatu kontrak (Asyraf Wajdi \& Nurdianawati 2014). Tanpa aset pendasar, sesuatu kontrak sukar untuk dilaksanakan dan boleh membawa kepada ketidakpatuhan Syariah (Madzlan Mohamad Hussain 2016). Melalui setiap kontrak yang dilaksanakan terdapat implikasi-implikasinya yang tertentu, hal ini termasuklah implikasi kepada pemilikan aset. Status pemilikan sesuatu aset hanya dapat ditentukan melalui kontrak yang digunakan.

Isu pemilikan menjadi isu yang hangat dibincangkan oleh sarjana Syariah dalam konteks kewangan Islam semasa. Di dalam praktis kewangan Islam, konsep pemilikan bermanfaat telah diguna pakai hampir dalam setiap produk yang ditawarkan. Jika dilihat dalam penstrukturan sukuk, konsep ini telah digunakan bagi membangunkan sekuriti ini (Engku Rabiah Adawiah 2014; Ramadhan Fitri 2013). Manakala bagi industri perbankan Islam pula, produk-produk seperti Bay' Bithaman Ajil, Al-Ijarah Thumma Al-Bay' (AITAB), Musharakah Mutanaqisah dan lain-lain produk dalam pembiayaan perumahan dan kenderaan turut tidak terkecuali mengguna pakai konsep pemilikan bermanfaat (Asyraf Wajdi \& Nurdianawati 2014).

\section{Kedudukan Pemilikan Bermanfaat Menurut Syariah}

Isu pemilikan bermanfaat telah menjadi perdebatan hangat dalam kalangan sarjana kontemporari. Sebahagian mereka mengiktiraf pemilikan bermanfaat sebagai pemilikan sebenar manakala sebahagian yang lain menolak pemilikan ini di sisi Syariah. Antara badan yang mengiktiraf pemilikan bermanfaat ialah Jawatankuasa Syariah Bank AlRajhi, Arab Saudi. Jawatankuasa tersebut menyatakan, aset yang dibeli daripada seseorang (penjual pertama) kemudian dijual kepada pihak ketiga, tetapi dalam masa yang sama nama aset masih lagi diletakkan pada penjual pertama atas dasar kelebihan cukai yang wujud. Pada transaksi pertama, nama Bank Al-Rajhi akan didokumentasikan dan disahkan oleh badan berautoriti. Walau bagaimanapun, jawatankuasa tersebut meletakkan beberapa syarat bagi melaksanakan transaksi tersebut antaranya:

1. Transaksi itu tidak dianggap sebagai satu bentuk penipuan dalam negara tersebut.

2. Kaedah ini merupakan satu bentuk penyelesaian undang-undang atau jalan keluar yang memberi manfaat kepada pihak yang terlibat (Jawatankuasa Syariah Bank Al-Rajhi 2010).

Selain itu, AAOIFI di dalam piawaian syariahnya turut menyebut mengenai isu pemilikan bermanfaat. Di dalam standard tersebut menyentuh mengenai konsep pembiayaan murabahah li al-amir bi al-shira'. Berdasarkan standard (8/5/4), bank dibenarkan untuk menunda pendaftaran atas nama pelanggan sebagai cagaran bagi 
pembayaran yang dibuat secara tangguh. Walau bagaimanapun, pihak bank haruslah mengemukakan dokumen yang menunjukkan bahawa aset tersebut merupakan milik pelanggan. Tatacara ini tidak menghalang perpindahan pemilikan kepada pihak pelanggan (Engku Rabiah Adawiah 2014).

Kedua-dua keputusan yang dikeluarkan oleh badan berautoriti tersebut mengiktiraf pemilikan aset seseorang walaupun namanya tidak didaftarkan ke atas aset. Justeru, segala kepentingan yang melibatkan hak-hak pemilik sebenar tidak terhalang dan perlu dibuktikan melalui dokumen-dokumen sokongan. Berdasarkan keputusan yang dibuat oleh Jawatankuasa Syariah Bank Al-Rajhi dan AAOIFI menunjukkan pemilikan bermanfaat diterima sebagai pemilikan sebenar di sisi syariah.

Dalam masa yang sama, isu mengenai pemilikan bermanfaat turut dibincang di peringkat Majlis Penasihat Syariah, Bank Negara Malaysia. Isu ini telah disentuh ketika membincangkan mengenai status pemilikan bermanfaat dalam kontrak sewaan kerana nama pemberi sewa tidak didaftarkan ke atas aset, sebaliknya didaftar ke atas penyewa. Di dalam mesyuarat yang ke-29 pada tarikh 25 September 2002 Bank Negara Malaysia (2010) telah memutuskan bahawa pemberi sewa merupakan pemilik sebenar walaupun namanya tidak didaftarkan. Keputusan ini dibuat berdasarkan pengiktirafan syariah terhadap pembahagian pemilikan bermanfaat (beneficial ownership) dan pemilikan undang-undang (legal ownership). Dalam konteks ijarah, pemberi sewa merupakan pemilik bermanfaat kerana namanya tidak didaftarkan. Pemilikan bermanfaat ini boleh dibuktikan sebagai pemilik sebenar melalui dokumen-dokumen yang dibuat di bawah perjanjian ijarah antara pemberi sewa dan penyewa.

Meskipun beberapa badan berautoriti mengiktiraf pembahagian pemilikan kepada pemilikan undang-undang dan pemilikan bermanfaat, terdapat juga pandangan yang tidak bersetuju mengenai pembahagian tersebut. Hussain Hamid Hassan antara sarjana yang tidak bersetuju bahawa pemilikan bermanfaat diterima di sisi Syariah kerana pemilikan dalam Islam telah jelas iaitu pemilik perlu memiliki pemilikan penuh ke atas aset untuk menjustifikasikan perolehan daripadanya dan hak untuk menjual aset tersebut. Pendapat ini turut disokong oleh Al-Amine kerana konsep pembahagian pemilikan ini bertentangan dengan kefahaman pemilikan di sisi Syariah. Konsep pemilikan dari perspektif Syariah meliputi pemilikan bermanfaat dan undang-undang, maka adalah mustahil untuk dipisahkan keduanya (Engku Rabiah Adawiah 2014). Walaupun begitu, pengiktirafan yang dilakukan oleh badan berautoriti seperti Jawatankuasa Syariah Bank Al-Rajhi, AAOIFI dan Majlis Penasihat Syariah Bank Negara Malaysia adalah berdasarkan syaratsyarat yang perlu dipatuhi untuk memastikan setiap hak berkaitan pemilikan terjamin.

Perlu diketahui, bagi menyelesaikan sesuatu isu yang timbul, sarjana Syariah perlu melihat kepada realiti semasa yang sedang dihadapi. Penggunaan konsep pemilikan bermanfaat terhasil daripada penerimaan konsep amanah dalam kerangka perundangan sesebuah negara (Safinaz Mohd Hussein 2016). Hal ini dijelaskan di dalam Akta UndangUndang Sivil 1956 seksyen 3 yang menyatakan penerimaan Common law di United Kingdom dan prinsip ekuiti dalam perundangan negara (Akta 67 2006). Penerimaan ini telah menatijahkan pembahagian pemilikan antara pemilik bermanfaat (beneficial owner) dan undang-undang (legal owner) diguna pakai dalam kerangka perundangan negara. Justeru, bagi mengharmonikan konsep pemilikan dari perspektif Islam dan perundangan 
sedia ada, satu parameter perlu diwujudkan untuk memastikan amalan perundangan hari ini tidak bertentangan dengan prinsip-prinsip Syariah.

\section{Aplikasi Pemilikan Bermanfaat dalam Kontrak Jual Beli Pembiayaan Perumahan Bay' Bithaman Ajil (BBA)}

Bay' Bithaman Ajil merupakan kaedah pembayaran yang boleh dilakukan dalam manamana kontrak jual beli sama ada Bay' Musawamah (jual beli tanpa merujuk harga asal) ataupun Bay' Murabahah (jual beli dengan menyatakan harga asal dan keuntungan) di mana pembayaran dibuat secara tangguh mengikut pada masa yang ditetapkan (Asyraf Wajdi \& Nurdianawati 2014).

Pelanggan yang berhasrat memiliki rumah kebiasaannya akan membayar duit pendahuluan (down payment) sebanyak 10 peratus kepada pemaju, dalam masa yang sama menandatangani Perjanjian Jual Beli (Sale and Purchase Agreement) (SPA). Dengan membayar wang pendahuluan dan menandatangani Perjanjian Jual Beli bersama pemaju, pelanggan layak diberikan pemilikan bermanfaat (beneficial ownership) terhadap aset tersebut.

Bagi membiayai baki harga rumah, pelanggan akan memohon pembiayaan melalui perbankan Islam menggunakan akad Bay' Inah. Pada proses ini, terdapat dua kontrak bebas yang perlu ditandatangani oleh pelanggan dan pihak bank iaitu Perjanjian Pembelian Aset (Property Purchase Agreement/PPA) dan Perjanjian Jualan Aset (Property Sale Agreement/PSA). Menerusi PPA, pihak bank akan membeli aset yang dimiliki pelanggan selaku pemilik bermanfaat. Harga aset yang dijual kepada pihak bank ialah bersamaan dengan jumlah yang diperlukan untuk membiayai harga rumah tersebut.

Selepas pihak bank memperolehi pemilikan aset melalui PPA, pihak bank akan menjual kembali aset yang sama kepada pelanggan dengan menandatangani PSA. Harga jualan tersebut adalah lebih tinggi daripada harga belian bank sewaktu PPA. Harga ini akan dibayar oleh pelanggan secara beransur-ansur sepanjang tempoh pembiayaan (Asyraf Wajdi \& Nurdianawati 2014).

Melalui Pembiayaan Perumahan Bay' Bithaman Ajil, pemilikan bermanfaat terhasil apabila pelanggan menandatangani Perjanjian Jual Beli bersama pemaju dan dalam masa yang sama membayar deposit harga rumah. Persetujuan antara pelanggan dan pemaju melalui Perjanjian Jual Beli menunjukkan akad jual beli telah berlaku. Oleh itu, pelanggan telah memiliki rumah tersebut dengan memperolehi pemilikan bermanfaat. Justeru, pelanggan bertanggungjawab untuk menyelesaikan baki harga rumah kepada pemaju. Fasa ini menjelaskan pemilikan bermanfaat terhasil walaupun nama pelanggan tidak didaftarkan. 


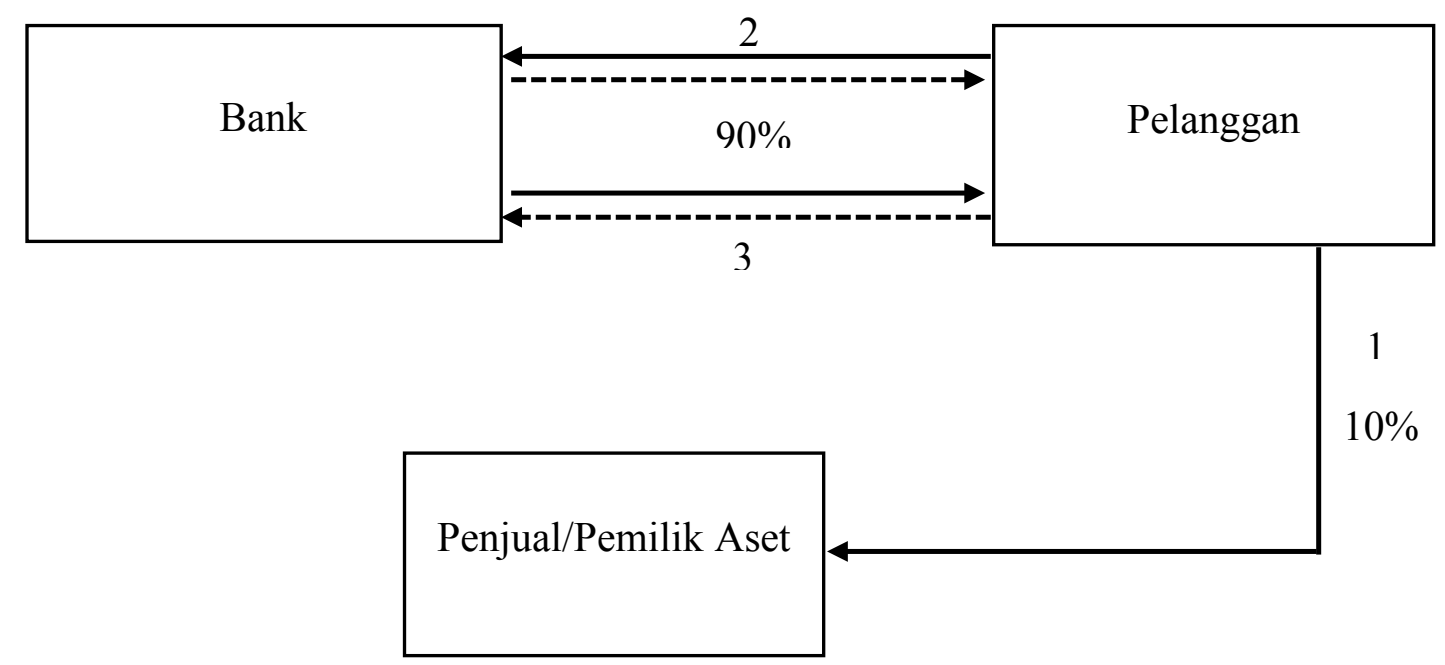

Diagram 1: Modus Operandi BBA dalam pembiayaan perumahan Sumber: (Asyraf Wajdi \& Nurdianawati 2014) dengan sedikit ubah suai

1. Pelanggan membayar deposit $10 \%$ kepada pemaju dan menerima pemilikan bermanfaat.

2. Pelanggan dan bank menandatangani Property Purchase Agreement dan Property Sale Agereement. Melalui pemilikan bermanfaat yang dimiliki, pelanggan menjual aset secara tunai kepada bank bagi mendapatkan pembiayaan BBA iaitu baki 90\% harga aset.

3. Bank selaku pemilik aset, menjual semula aset tersebut kepada pelanggan dengan bayaran secara tangguh.

\section{Aplikasi Pemilikan Bermanfaat dalam Kontrak Sewaan Pembiayaan Perumahan Al-Ijarah Al-Muntahiyat Bi Al-Tamlik (IMBT)}

Pembiayaan perumahan yang berasaskan IMBT mengguna pakai kontrak sewaan yang berakhir dengan perpindahan pemilikan melalui pendaftaran nama aset kepada penyewa (Kuwait Finance House 2015; Maybank Islamic 2013; OCBC Al-Amin t.th.). Perpindahan hak milik berlaku samada dengan kaedah jualan atau aset tersebut dihibahkan kepada penyewa. Fasiliti ini hanya disediakan bagi rumah yang sudah siap dibina sahaja (Asyraf Wajdi \& Nurdianawati 2014).

Langkah pertama untuk melaksanakan pembiayaan IMBT ialah pelanggan akan mengenal pasti aset yang diingini terlebih dahulu. Aset tersebut mestilah aset yang sudah siap dibina. Seterusnya, pelanggan akan memohon pembiayaan daripada bank untuk rumah yang sudah dikenal pasti tersebut. Pelanggan perlu membayar deposit kepada pihak bank bagi membolehkan bank membeli aset tersebut dengan membayar harga penuh ( $10 \%$ deposit dan $90 \%$ pembiayaan diperlukan) kepada pemaju.

Pendekatan lain yang mungkin boleh diambil ialah pelanggan membayar deposit terus kepada pemaju. Dalam hal ini, wang deposit yang dibayar oleh pelanggan dianggap 
sebagai hamish jiddiyah ataupun urbun (Bank Negara Malaysia 2010). Deposit yang dibayar oleh pelanggan merupakan bayaran deposit oleh pelanggan kepada bank melalui pemaju (Mohammad Mahbub Ali, Mohd Faiz Rahim 2016). Apabila akad jual beli terlaksana, bank yang menjadi pemilik aset tersebut akan menyewakannya kepada pelanggan mengikut tempoh yang ditetapkan. Pada akhir tempoh sewaan, pelanggan akan memiliki aset tersebut dengan membelinya melalui akad berasingan (Kuwait Finance House 2015).

Berdasarkan amalan yang dilaksana oleh Maybank Islamic (2013) dan OCBC AlAmin (t.th.), pelanggan terlebih dahulu perlu membeli aset daripada pemaju dengan membayar deposit. Apabila aset sudah menjadi milik pelanggan menerusi pemilikan bermanfaat yang diperolehinya, pelanggan akan menjual aset tersebut kepada bank dengan nilai bersamaan jumlah pembiayaan. Keadaan ini menjadikan bank selaku pemilik baru aset tersebut. Selaku pemilik aset, bank menyewakan aset kepada pelanggan dengan harga dan tempoh yang dipersetujui. Di akhir sewaan, pihak bank akan menjual aset kepada pelanggan dengan harga yang dipersetujui bersama.

Di dalam kontrak ijarah, pemberi sewa merupakan pemilik aset sementara penyewa hanya berhak mendapat manfaat daripada aset sahaja. Walau bagaimanapun, praktik amalan semasa tidak mendaftarkan nama pemberi sewa sebagai penama berdaftar sebaliknya nama penyewa yang didaftarkan. Hal ini menimbulkan isu samada pemberi sewa memiliki aset tersebut ataupun tidak. Bank Negara Malaysia (2010) melalui Majlis Penasihat Syariahnya telah memutuskan di dalam mesyuarat yang ke-29 bertarikh 25 September 2002 bahawa pemberi sewa merupakan pemilik aset walaupun namanya tidak didaftarkan. Ini berdasarkan pemilikan bermanfaat yang dimiliki oleh bank sementara pelanggan hanyalah pemilik berdaftar.

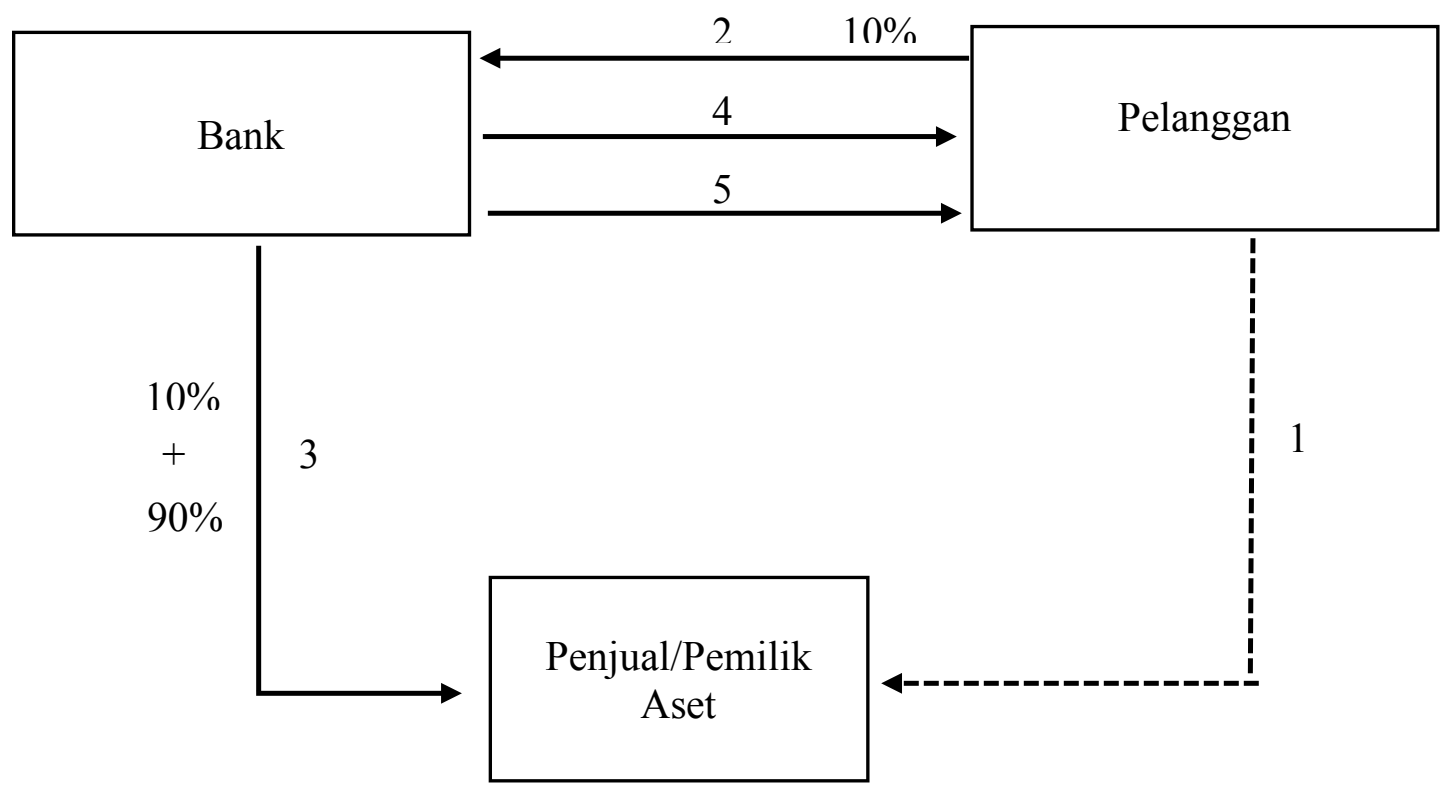

Diagram 2: Modus Operandi IMBT dalam pembiayaan perumahan Sumber: (Mohammad Mahbub Ali, Mohd Faiz Rahim 2016) dengan sedikit ubah suai 
1. Pelanggan mengenal pasti aset.

2. Pelanggan memohon pembiayaan IMBT dan membayar deposit terus kepada bank. Kaedah lain, pelanggan menjadi wakil bank membayar deposit kepada pemaju.

3. Bank membeli aset dengan membayar harga penuh $(10 \%$ deposit $+90 \%$ baki $)$ kepada pemaju.

4. Bank selaku pemilik bermanfaat menyewakan aset kepada pelanggan dengan bayaran dan tempoh yang dipersetujui dan berjanji akan menyerahkan pemilikan kepada pelanggan pada akhir tempoh sewaan.

5. Pada akhir tempoh sewaan bank menyerahkan pemilikan kepada pelanggan.

\section{Aplikasi Pemilikan Bermanfaat dalam Kontrak Perkongsian Pembiayaan Perumahan Musharakah Mutanaqisah (MM)}

Secara umumnya, berikut merupakan langkah-langkah yang berlaku dalam pembiayaan Musharakah Mutanaqisah:

1. Langkah pertama:

i. Pelanggan mengenal pasti kediaman yang ingin dibeli dan memohon pembiayaan daripada bank.

ii. Pelanggan dan bank akan memasuki kontrak MM yang bertujuan untuk memiliki rumah secara perkongsian.

iii. Pembayaran deposit daripada pelanggan akan menjadi caruman terhadap perkongsian tersebut, manakala baki harga rumah akan dicarum oleh bank sebagai rakan kongsi. (Jumlah caruman bank merupakan amaun pembiayaan).

2. Langkah kedua:

i. Bank selaku pencarum terbesar dalam perkongsian akan menyewakan aset tersebut kepada pelanggan.

ii. Praktis semasa yang berlaku ialah bank akan menyewakan bahagiannya kepada pelanggan. Keseluruhan bayaran sewaan akan menjadi milik bank.

iii. Bayaran sewa yang dikenakan adalah sama dengan kadar keuntungan yang dikenakan oleh bank konvensional.

3. Langkah ketiga:

i. Sepanjang tempoh sewaan pada jarak waktu yang dipersetujui, pelanggan akan membeli unit-unit yang mewakili bahagian bank dalam aset. Hal ini dilaksanakan apabila pelanggan dikehendaki membayar sejumlah amaun tambahan ketika membayar sewa kepada pihak bank sebagai pembelian bahagian bank dalam aset (kontrak jual beli berlaku). Bahagian bank akan berkurangan setiap kali pembelian unit oleh pelanggan. 
ii. Pada akhir tempoh sewaan, aset akan dimiliki sepenuhnya oleh pelanggan dan nama pemilikan aset akan diserah kepada pelanggan. Kontrak MM berakhir.

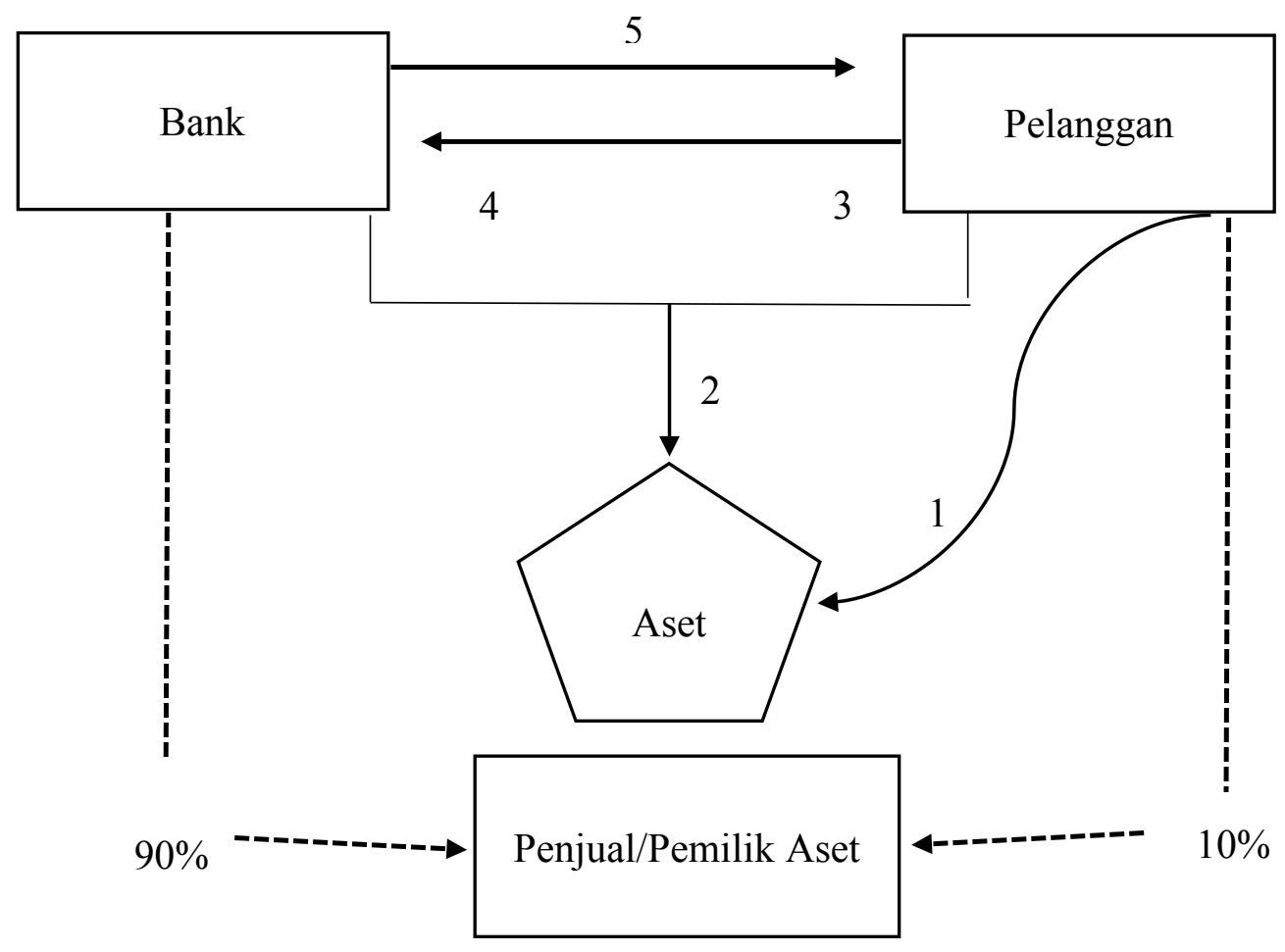

Diagram 3: Modus Operandi MM dalam pembiayaan perumahan Sumber: (Rafe Haneef, Sherin Kunhibava 2011) dengan sedikit ubah suai

1. Pelanggan mengenal pasti aset, tandatangani Perjanjian Jual Beli (S\&P), bayar deposit $10 \%$ dan memohon pembiayaan bank.

2. Bank dan pelanggan memasuki aturan Musharakah Mutanaqisah.

3. Pelanggan menyewa aset daripada bank.

4. Pelanggan membeli bahagian bank dengan membayar amaun tambahan.

5. Perkongsian berakhir dan pelanggan memiliki 100\% pemilikan aset (nama pemilik akan diserah kepada pelanggan).

Melalui pembiayaan perumahan Musharakah Mutanaqisah, pemilikan bermanfaat terhasil setelah pelanggan dan bank memasuki kontrak jual beli bersama pemaju. Pelanggan dan bank mengeluarkan sumbangan masing-masing (yang disepakati) bagi mendapatkan aset. Hasilnya pihak bank dan pelanggan telah menjadi pemilik bersama ke atas aset. Walau bagaimanapun, bank bersetuju untuk mendaftarkan aset ke atas nama pelanggan dan hanya menjadi pemilik bermanfaat sahaja. 
Majoriti bank mengamalkan pendaftaran nama aset ke atas nama pelanggan. Terdapat dua sebab utama mengapa kaedah ini digunakan. Sebab pertama ialah persepsi pelanggan yang terbiasa dengan amalan gadaian konvensional yang meletakkan pelanggan sebagai penama berdaftar. Sebab kedua kerana bank tidak mahu menanggung sebarang liabiliti jika berlaku sesuatu ke atas aset terutama yang melibatkan tuntutan tertentu (Rafe Haneef et al. 2011).

Melalui amalan semasa, pelanggan merupakan pemilik undang-undang kerana namanya didaftarkan ke atas aset berdasarkan persetujuan bank. Sementara itu, pelanggan dan bank merupakan pemilik bermanfaat secara bersama. Pelanggan selaku pemilik undang-undang, bertindak selaku pemegang amanah bagi pemilik bermanfaat iaitu dirinya sendiri dan bank. Dalam erti kata lain, pelanggan merupakan pemilik undangundang, pemegang amanah dan pemilik bermanfaat, sementara bank hanya bertindak sebagai pemilik bermanfaat sahaja.

\section{Konsep Pemilikan Bermanfaat dalam Pembiayaan Perumahan Menurut Syariah}

Implikasi daripada sesuatu kontrak jual beli menyebabkan berlakunya perpindahan hak pemilikan. Natijah daripada kontrak jual beli mengakibatkan setiap pihak yang berkontrak perlu saling bertukar pemilikan iaitu pembeli menjadi pemilik baru kepada barang yang dibeli. Sementara penjual menjadi pemilik kepada harga yang dibayar oleh pembeli. Selain itu, setiap pihak perlu saling menyerahkan barang yang sudah bertukar pemilikan tersebut. Hal ini seperti dijelaskan oleh

al-Kasani (1986) dalam al-Bada'i al-Sana'i:

$$
\text { عقد معاو ضنة تمليك بتمليك وتسليم بتسليم }
$$

Maksudnya: Kontrak pertukaran iaitu saling bertukar pemilikan dan saling membuat penyerahan.

Ibn Qudamah (1968) di dalam al-Mughni:

$$
\text { مبادلة المال بالمال تمليكًا وتملكًا }
$$

Maksudnya: Pertukaran harta dengan harta, bagi memindahkan pemilikan dan mengambil pemilikan.

Dalam pembiayaan perumahan BBA, ketika pihak pelanggan menandatangani Perjanjian Jual Beli bersama pemaju dengan membayar deposit, proses ijab dan qabul telah berlaku. Perkara yang sama turut berlaku ketika proses awal pembiayaan IMBT, sekiranya pelanggan membeli rumah terlebih dahulu daripada pemaju seperti yang diamalkan Maybank Islamic (2013). Apabila kontrak jual beli telah terlaksana, keduadua pihak perlu melaksanakan tanggungjawab masing-masing. Pemaju perlu menyerahkan aset kepada pembeli dan pembeli perlu melangsaikan hutangnya kepada pemaju. Menurut syarak, perpindahan pemilikan telah berlaku walaupun nama aset tidak didaftarkan ke atas pelanggan. Syariah melihat kontrak ini sebagai kontrak yang sah. Oleh itu selaku pemilik bermanfaat, pelanggan berhak menjual aset tersebut kepada bank bagi mendapatkan baki pembiayaan. 
Pemilikan bermanfaat merupakan pemilikan penuh yang dipegang oleh pelanggan walaupun nama aset merupakan nama orang lain. Hal ini bertitik tolak di atas asas syariah yang tidak mewajibkan pendaftaran dilakukan. Pendaftaran pemilikan merupakan perbuatan yang dianjurkan bagi menjamin keselamatan dan kepentingan pemilik aset. Syariah melihat pendaftaran hanyalah urusan pentadbiran yang menjadi keperluan dibawah undang-undang sivil. Situasi ini tidak bercanggah dengan kehendak Syariah mahupun undang-undang semasa yang terpakai.

Firman Allah:

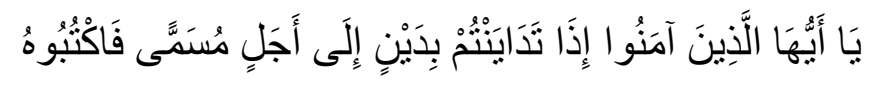

Maksudnya: Wahai orang-orang yang beriman! Apabila kamu menjalankan sesuatu urusan dengan hutang piutang yang diberi tempoh hingga ke suatu masa yang tertentu, maka hendaklah kamu menulis (hutang dan masa bayarannya) itu (al-Baqarah: 282).

Walaupun pada asalnya suruhan adalah perintah wajib, namun suruhan menulis (hutang) dalam ayat tersebut bukan bersifat wajib. Apabila terdapat petunjuk lain yang menerangkan hakikat sebenar, suruhan tersebut bertukar menjadi sesuatu yang dianjurkan (al-Zuhayli 2005). Ini kerana, dalam ayat seterusnya, Allah berfirman:

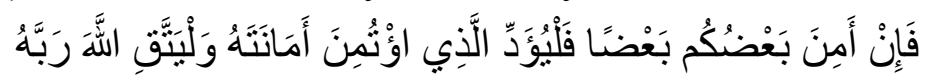

Maksudnya: Jika sebahagian kamu mempercayai sebahagian yang lain, maka hendaklah yang dipercayai itu menunaikan amanatnya (hutangnya) dan bertakwalah kepada Allah (al-Baqarah: 283).

Al-Nawawi (t.th.) menukilkan kata-kata Imam al-Syafie dalam Majmu':

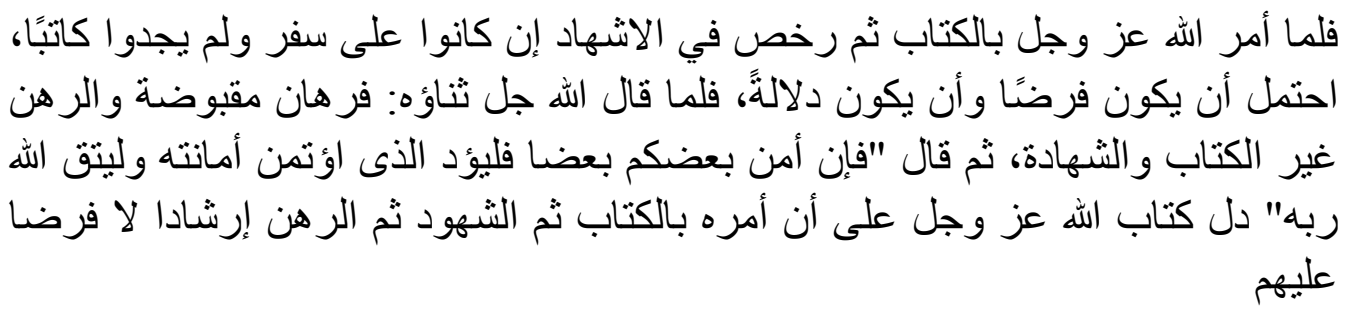

Maksudnya: Ketika suruhan Allah untuk menulis (hutang), seseorang diberi keringanan jika berada dalam permusafiran kerana tidak menjumpai penulis, dalam hal ini terdapat kemungkinan suruhan tersebut berbentuk wajib ataupun anjuran sahaja, ketika Allah mengarahkan untuk mengadai barang dan bukannya menulis mahupun penyaksian, datang suruhan lain iaitu: jika sebahagian kamu mempercayai sebahagian yang lain, maka hendaklah yang dipercayai itu menunaikan amanatnya (hutangnya). Ini menunjukkan suruhan Allah untuk menulis (hutang) kemudian penyaksian dan gadaian adalah bersifat anjuran bukannya kewajipan.

Isu penulisan hutang boleh diqiyaskan kepada isu pendaftaran pemilikan kerana mempunyai 'illah yang sama iaitu pendokumentasian. Dokumentasi memerlukan penulisan ke atas sesuatu transaksi direkodkan untuk menjamin keselamatan dan kepentingan pihak yang terlibat. Apabila sesuatu transaksi direkodkan, pihak yang terlibat boleh merujuk kembali dokumen berkaitan apabila berlaku pertelingkahan ataupun tuntutan tertentu daripada mana-mana pihak. Dengan itu, sebarang pertelingkahan dapat diselesaikan dengan adil dan mudah-mudahan memenuhi tuntutan masing-masing. 
Ketika proses jual beli antara pelanggan dan pemaju berlangsung, hakmilik undangundang (legal title) aset masih lagi berada pada pemaju. Walau bagaimanapun, dalam dokumen Perjanjian Jual Beli, pengesahan pemilikan dinyatakan bahawa pemilikan akan didaftarkan sebaik sahaja bayaran penuh dilakukan oleh pelanggan. Kewujudan perjanjian ini adalah bagi melindungi kedua-dua hak pelanggan dan penjual (Mohd Hazami Abdul Samat 2016). Biarpun hakmilik undang-undang (legal title) masih di tangan pemaju, pelanggan telah pun memiliki kepentingan benefisial terhadap aset. Melalui kepentingan benefisial ini, pelanggan berhak menjual aset kepada bank bagi mendapatkan pembiayaan. Hak menjual ini merupakan antara sifat pemilikan yang diiktiraf di sisi syarak, seperti yang disebut Ibn Taimiyyah (2005):

$$
\text { القدرة الشرعية على التصرف في الرقبة }
$$

Maksudnya: Keupayaan yang sah untuk mengendalikan sesuatu harta.

Tambahan pula, bagi menjamin keselamatan dan kepentingan pihak yang terlibat, hak pemilikan perlu dikuatkuasakan melalui dokumen tambahan sebagai bukti bertulis. Bank Negara Malaysia (2013) dalam Piawaian Murabahah 23.17 menetapkan hak pemilikan aset perlu dibuktikan melalui dokumen tambahan bagi mengesahkan pemilikan. Pemilikan yang dibuktikan melalui dokumentasi mestilah pemilikan yang sebenar. Biarpun hakmilik undang-undang (legal title) aset dipegang oleh pemaju, namun dokumen tambahan tersebut mencukupi bagi membuktikan pemilikan aset sudah berpindah milik.

Bagi pembiayaan perumahan Musharakah Mutanaqisah, pemilikan bermanfaat terhasil setelah pelanggan dan bank memasuki kontrak jual beli bersama pemaju. Pelanggan dan bank mengeluarkan sumbangan masing-masing (yang disepakati) bagi mendapatkan aset. Hasilnya pihak bank dan pelanggan telah menjadi pemilik bermanfaat secara bersama. Walau bagaimanapun, bank bersetuju untuk mendaftarkan aset ke atas nama pelanggan. Ini menjadikan pelanggan sebagai pemilik berdaftar seterusnya pemegang amanah ke atas aset. Sebagai pemegang amanah, pelanggan akan mendaftarkan gadaian undang-undang (legal charge) ke atas aset kepada pihak bank sebagai cagaran.

Walaupun hakmilik undang-undang (legal title) diletakkan di bawah nama pelanggan, bank juga merupakan pemilik kepada aset tersebut bersama dengan pelanggan berdasarkan prinsip shirkah (perkongsian). Piawaian Syariah Musyarakah oleh Bank Negara Malaysia (2015) menetapkan kontrak Musharakah Mutanaqisah perlu dikawal selia mengikut prinsip perkongsian pemilikan (shirkah al-milk) dan mempunyai kesan perkongsian pemilikan. Pelanggan yang dipilih sebagai pemilik berdaftar adalah bagi melicinkan urusan pentadbiran iaitu sebagai pemegang amanah ke atas aset tersebut. Pendaftaran pemilikan ke atas pelanggan hanyalah bagi memenuhi tuntutan undangundang semasa dan sama sekali tidak menafikan sifat-sifat pemilikan yang digariskan syarak. Kaedah ini memberikan satu bentuk penyelesaian undang-undang atau jalan keluar yang memberi manfaat kepada pihak yang terlibat (Jawatankuasa Syariah Bank Al-Rajhi 2010).

Sementara itu, perundangan tempatan telah mengiktiraf pemilikan bermanfaat sebagai pemilikan sebenar walaupun nama orang lain yang didaftarkan ke atas aset. 
Sekalipun pemilik undang-undang merupakan orang lain, ini tidak menafikan hak yang diperolehi oleh pemilik manfaat ke atas aset. Prinsip ekuiti yang diterima pakai dalam perundangan negara seperti yang dijelaskan dalam seksyen 3 Akta Sivil 1956 dan seksyen 206(3) Kanun Tanah Negara 1965 tidak menghalang pengwujudan kepentingan benefsial dalam hal tanah melalui amanah nyata, tersirat atau berbangkit yang wujud melalui pengoperasian undang-undang di Malaysia (Siti Noorafizah Azizan 2009).

Setelah meneliti pemilikan bermanfaat dari perspektif syariah, dapat disimpulkan bahawa pemilikan bermanfaat merupakan pemilikan sebenar. Ini ditegaskan lagi oleh Islamic Finance Law Harmonisation Committee (Bank Negara Malaysia 2013: 97) bahawa pemilikan bermanfaat ialah " a person who enjoys the benefits of land ownership even though the land title is in another's name". Ini menunjukkan bahawa pemilik benefisial ialah pemilik sebenar dari segi undang-undang yang menikmati segala manfaat dan faedah aset meskipun tidak mempunyai hakmilik undang-undang (legal title). Namun, persoalan yang timbul ialah apakah takyif fiqhi yang sesuai bagi pemilikan bermanfaat untuk pembiayaan perumahan?

Menurut Nik Abdul Rahim (2015) bagi menganalisis takyif fiqhi yang sesuai bagi pemilikan bermanfaat perlu melihat kepada skop transaksi yang diperuntukan dalam undang-undang. Undang-undang yang terlibat bagi transaksi tanah di Malaysia iaitu Kanun Tanah Negara 1965 yang memberi kelonggaran dalam penggunaan prinsip ekuiti dalam perundangan. Beliau mencadangkan sekurang-kurangnya terdapat empat konsep yang saling berkaitan bagi melakukan takyif fiqhi iaitu konsep rahn, khiyar naqd, bai' alwafa dan shurut taqyidiyyah. Walau bagaimanapun, keempat-empat takyif fiqhi ini tertakluk kepada penggunaan terma pemilikan bermanfaat dalam kontrak-kontrak tertentu.

\section{KESIMPULAN}

Berdasarkan perbincangan di atas, dapat disimpulkan bahawa pemilikan bermanfaat merupakan pemilikan penuh ke atas aset. Pemilik bermanfaat ialah pemilik sebenar sesuatu aset walaupun namanya tidak didaftarkan. Transaksi yang melibatkan pertukaran hak milik telah menjadikan pemilikan bermanfaat sebagai satu instrumen penting bagi memelihara hak-hak pihak yang melakukan transaksi di mana harta tersebut menjadi amanah bagi pihak yang akan melakukan pertukaran hak milik.

Berdasarkan sejarah, pemilikan bermanfaat wujud dalam prinsip ekuiti yang diamalkan dalam sistem undang-undang Inggeris di United Kingdom. Pada hari ini, terma ini telah diaplikasikan dalam kebanyakan transaksi komersil moden samada melibatkan jual beli tanah ataupun barangan. Industri kewangan Islam tidak terkecuali bergelut dalam penggunaan terma ini. Terma pemilikan bermanfaat berlegar apabila pemilik sebenar sedang berusaha mendaftarkan aset ke atas namanya.

Namun, pemilikan bermanfaat yang diiktiraf sebagai pemilikan sebenar perlu memiliki setiap ciri pemilikan seperti yang telah digariskan oleh syariah. Sebagai tambahan, aplikasi pemilikan bermanfaat dalam kewangan Islam perlu dianalisis dengan 
lebih kritis berdasarkan setiap produk yang ditawarkan. Hal ini kerana setiap produk adalah berbeza antara satu sama lain.

\section{PENGHARGAAN}

Artikel ini merupakan sebahagian daripada hasil penyelidikan Pembinaan Parameter Syariah Prinsip Pemilikan Bermanfaat (Beneficial Ownership) dalam Kewangan Islam di bawah dana FRGS/1/2015/SS01/UKM/03/2.

\section{RUJUKAN}

Al-Quran.

Asyraf Wajdi \& Nurdianawati. 2014. Fundamentals of Islamic Banking. ${ }^{\text {nd }}$ Ed. Selangor: IBFIM.

Badran, Abu al-Aynayn. t.th. Tarikh al-Fiqh al-Islami wa Nazariyyah al-Milkiyyah wa al-Uqud. Beirut, Lubnan: Dar al-Nahdah al-Arabiyyah.

Bank Negara Malaysia. 2010. Shariah resolution in Islamic finance. Bank Negara Malaysia.

Bank Negara Malaysia. 2013. Shariah Standard on Murabahah. Issued by Islamic Banking and Takaful Department, BNM (Issued on 23 December 2013).

Bank Negara Malaysia. 2015. Musyarakah. Issued by Islamic Banking and Takaful Department, BNM (Issued on 20 April 2015).

Burke, John. 1977. Jowitt's Dictionary of English Law. $2^{\text {nd }}$ Ed. Great Britain: Sweet \& Maxwell Ltd.

Engku Rabiah Adawiah. 2014. Legal Ownership dan Beneficial Ownership Menurut Perspektif Syarak dan Undang-Undang. Kuala Lumpur.

Garner, Bryan A. 2004. Black's Law Dictionary. Bryan A. Garner (pnyt.). $8^{\text {th }}$ Ed. United State of America: West, a Thomson Business.

Hudson, Alastair. 2007. Equity and Trusts. $5^{\text {th }}$ Ed. United State of America: Routledge-Cavendish.

Ibn Hummam, Kamal. t.th. Fath al-Qadir. Arab Saudi: Wizarah al-Shu'un al-Islamiyyah wa al-Awqaf wa al-Dakwah wa al-Irshad.

Ibn Nujaym, Zayn al-Din bin Ibrahim. 1999. Ashbah wa al-Naza 'ir li Ibn Nujaym. Beirut, Lubnan: Darul Kutub Ilmiyyah.

Ibn Qudamah. 1968. al-Mughni. t.tp: Maktabah al-Qahirah.

Ibn Rajab, Abd al-Rahman. t.th. al-Qawa id li Ibn Rajab. t.tp.: Dar al-Fikr.

Ibn Taimiyyah, Taki al-Din. 2005. Majmu’ al-Fatawa. Mansurah, Mesir: Darul Wafa.

Jawatankuasa Syariah Bank Al-Rajhi. 2010. Keputusan Jawatankuasa Syariah Bank Al-Rajhi. Riyadh, Arab Saudi: Dar Kunuz Isybiliiyya.

al-Kasani. 1986. al-Bada'i al-Sana'i fi Tartib al-Shara'i. Dar al-Kutub al-Ilmiyyah.

Kuwait Finance House. 2015. Product Disclosure Sheet Kuwait Finance House Home Financing-i. 1-7.

Lembaga Penyelidikan Undang-Undang, ed. 2008. Kamus Undang-Undang. Selangor, Malaysia: International Law Book Services.

Madzlan Mohamad Hussain. 2016. Pemunyaan Benefisial dalam Perbankan Islam \& Pasaran Modal Islam.

Malaysia. 2006. Civil Law Act 1956 [Act 67].

Malaysia. 2006. Kanun Tanah Negara 1965 [Akta 56].

Manzur, Ibn, Ibn Manẓūr, Muhammad ibn Mukarram, \& Manzur, Ibn. 1955. Lisan al-Arab. Beirut, Lubnan:

Dar al-Sadir.

Maybank Islamic. 2013. Ijarah Term Financing-i.

http://www.maybank2u.com.my/Islamic/en/business/financing/ijarah-term-financing-i.page

[June 14, 2016]. 
Mohammad Mahbub Ali, Mohd Faiz Rahim \& Mohd Shukor Abdullah. 2016. Adaptasi fiqh (takyif fiqhi) terhadap bayaran pendahuluan dalam produk AITAB di Malaysia. Dlm. Muzakarah Cendiakawan Syariah Nusantara Ke-10, Kuala Lumpur.

Mohd Hazami Abdul Samat. 2016. Justifikasi Penggunaan Pemilikan Bermanfaat dalam Kewangan Islam, Kuala Lumpur. Temu bual, 19 Mei.

al-Nawawi. t.th. Majmu' Sharh al-Muhazzab. Dar al-Fikr.

Nik Abdul Ghani, Nik Abdul Rahim, Saleem, Muhammad Yusuf, \& Lahsasna, Ahcene. 2015. Beneficial ownership: to what extent it complies with shari'ah? Asian Social Science 11(27): 155-67.

Nor Asiah Mohamad. 2008. Analysing the equitable spirit of section 206 of the National Land Code. Malayan Law Journal 3: 44-62.

Oakley, A. J. 1998. Parker and Mellows: The Modern Law of Trust. $7^{\text {th }}$ Ed. London: Sweet \& Maxwell Ltd.

OCBC Al-Amin. t.th. Manarat Home-i. https://www.ocbc.com.my/OCBCAl_Amin/pb_financing.shtml?utm_source=ocbc_loans\&utm_

medium $=$ txt_links_more\&utm_campaign $=$ ocbc_loans_islamic_home_financing\#Manarat Home-i [January 1, 2016].

Pearce, Robert \& John Stevens \& Warren Barr. 2010. The Law of Trusts and Equitable Obligations. $5^{\text {th }}$ Ed. New York: Oxford University Press Inc.

al-Qarafi, Shihab al-Din Abi Abbas. 2003. al-Furuq li Imam al-Qarafi. Beirut, Lubnan: Muassasah alRisalah.

Rafe Haneef, Sherin Kunhibava \& Edib Smolo. 2011. Musharakah mutanaqisah and legal issues: case study of Malaysia 3: 91-122.

Ramadhan Fitri, Nasir Haron \& Faysal. 2013. Shariah issues in sukuk. Shariah Forum KLIFF.

Safinaz Mohd Hussein. 2016. Beneficial ownership menurut perspektif undang-undang \& pemakaiannya di Malaysia. Dlm. Diskusi Meja Bulat Pemilikan Bermanfaat (Beneficial Ownership) dalam Kewangan Islam. Anjuran Projek Penyelidikan FRGS Pembinaan Parameter Syariah Prinsip Pemilikan Bermanfaat dalam Kewangan Islam (FRGS/1/2015/SS01/UKM/03/2). Selangor, 3 Mei.

Siti Noorafizah Azizan, Masliza Mohamad \& Safinaz Mohd Hussein. 2009. Pemakaian ekuiti di Malaysia dlm Isu-Isu Perundangan di Malaysia: Satu Anjakan Paradigma. UKM: Fakulti Undang-undang. hlm. 59-86.

al-Suyuti, Jalal al-Din bin Abd al-Rahman. 1983. al-Ashbah wa al-Naza'ir li al-Suyuti. Beirut, Lubnan: Dar al-Kutub Ilmiyyah.

al-Umari, Fahd Abdullah. 2003. Naza' al-Milkiyyah al-Khassah wa Ahkamuha fi al-Fiqh al-Islami. Edisi Pert. Riyadh, Arab Saudi: Universiti Imam Muhammad bin Saud.

al-Zuhayli, Wahbah. 2005. Usul al-Fiqh al-Islami. Damsyik: Dar al-Fikr.

Nik Abdul Rahim Nik Abdul Ghani

nikrahim@ukm.edu.my

Mat Noor Mat Zain

mnmz@ukm.edu.my

Salmy Edawati Yaacob

salmy1001@ukm.edu.my

Ahmad Dahlan Salleh

dahlan@ukm.edu.my

Amir Fazlim Yusoff

amiry@ukm.edu.my

Jabatan Syariah,

Fakulti Pengajian Islam,

Universiti Kebangsaan Malaysia,

43600 Bangi, Selangor,

MALAYSIA 
Ruzian Markom

ruzian@ukm.edu.my/tdfuu@ukm.edu.my

Fakulti Undang-undang,

Universiti Kebangsaan Malaysia,

43600 Bangi, Selangor,

MALAYSIA

Mohammad Firdaus Mohammad Hatta

firdaus5828@salam.uitm.edu.my

Arshad Ayub Graduate Business School,

Faculty of Business Management, UiTM, Shah Alam,

40450, Selangor.

Hanzalah Zainal

Postgraduate Student

hanzalahzainal90@gmail.com

Jabatan Syariah,

Fakulti Pengajian Islam,

Universiti Kebangsaan Malaysia,

43600 Bangi, Selangor,

MALAYSIA 
Journal of Contemporary Islamic Law

Vol. 1(2) (2016)

\section{Editor-In-Chief}

Dr. Mohd Al Adib Samuri

\section{Co-Editor}

Dr. Salmy Edawati Yaacob

\section{Senior Editors}

Prof. Dr. Abdul Basir Mohamad Prof. Dr. Mohd Nasran Mohamad Assoc. Prof. Dr. Shofian Ahmad Assoc. Prof. Dr. Zaini Nasohah Assoc. Prof. Dr. Ibnor Azli Ibrahim Assoc. Prof. Dr. Zuliza Mohd Kusrin

Chief Managing Editor

Dr. Mat Noor Mat Zain

Arabic Copy Editor

Anwar Fakhri Omar

\section{Bahasa Copy Editor}

Dr. Mohd Zamro Muda

Md. Yazid Ahmad

\section{Editor}

Dr. Mohammad Zaini Yahaya Nik Abd. Rahim Nik Abdul Ghani 
Journal of Contemporary Islamic Law

Vol. 1(2) (2016)

Published by:

Jabatan Syariah,

Fakulti Pengajian Islam,

Universiti Kebangsaan Malaysia,

43600 Bangi, Selangor, Malaysia

Suggested citation style

Author, (2016), Title, Journal of Contemporary Islamic

Law, 1(2), pages, http://www.ukm.my/jcil

eISSN 0127-788X

This work is licensed under a Creative Commons Attribution-Noncommercial-No Derivative Works 3.0 Unported License

(http://creativecommons.org/licenses/by-nc-nd/3.0/).

You can download an electronic version online. You are free to copy, distribute and transmit the work under the following conditions: Attribution - you must attribute the work in the manner specified by the author or licensor (but not in any way that suggests that they endorse you or your use of the work); Noncommercial - you may not use this work for commercial purposes; No Derivate Works - you may not alter, transform, or build upon this work. 